DOI:10.17951/h.2015.49.4.155

\begin{tabular}{lcl}
\hline \multicolumn{1}{c}{ A N N A L E S } \\
UNIVERSITATIS & MARIAE CURIE-SKŁODOWSKA \\
LUBLIN - POLONIA & SECTIOH H \\
VOL. XLIX, 4 & 2015 \\
\hline
\end{tabular}

Uniwersytet Ekonomiczny w Katowicach, Wydział Finansów i Ubezpieczeń

\title{
WITOLD GRADOŃ
}

wgradon@ue.katowice.pl

\section{Nowa ustawa o obligacjach szansa na ożywienie rynku dtugu nieskarbowego $w$ Polsce}

The New Act on Bonds Opportunity to Revitalize the Non-Treasure Debt Market in Poland

Słowa kluczowe: rynek obligacji, obligacje nieskarbowe

Keywords: bond market, non-treasury bonds

Kod JEL: G10

\section{Wstęp}

Bliski zera poziom stóp procentowych powinien stanowić najlepszy czas dla podmiotów gospodarczych na zwiększenie skali finansowania w drodze zaciągania długu. W polskich warunkach nie sprzyja temu jednak niska efektywność rynku instrumentów dłużnych. 1 lipca 2015 r. weszła w życie nowa ustawa o obligacjach, która stworzyła nowe możliwości emitentom i zwiększyła zarazem bezpieczeństwo inwestorów. Wydaje się zatem, że nowe, bardziej przejrzyste i dokładniejsze przepisy sprawią, że obligacje będą miały szansę stać się realnie istotnym i komplementarnym do kredytów bankowych źródłem pozyskiwania kapitału obcego, a tym samym będą wspierać rozwój rynku długoterminowych nieskarbowych papierów dłużnych. Zmiany w prawie wymagają przy tym innego podejścia do organizacji emisji obligacji oraz świadomości skutków wprowadzenia nowych rozwiązań. Można przyjąć hipotezę, że zmiany zapisów ustawy o obligacjach będą stanowić istotny bodziec skutecznie stymulujący stopniowe ożywienie rynku nieskarbowych instrumentów dłużnych w Polsce. 
Celem niniejszego artykułu jest analiza rynku obligacji nieskarbowych, identyfikacja barier jego rozwoju i przybliżenie zmian, jakie przewiduje nowy tekst ustawy o obligacjach wraz z próbą ukazania ich wpływu na zwiększenie popularności rynku długu nieskarbowego w Polsce.

\section{Analiza rynku nieskarbowych papierów dłużnych w Polsce}

Rynek nieskarbowych papierów dłużnych w Polsce osiągnął na koniec $2014 \mathrm{r}$. wartość 140 mld zł. Oznacza to, że w latach 2009-2014 wolumen emisji niemal się podwoił, przy czym największy wzrost odnotowano w przypadku długu przedsiębiorstw - wartość emisji obligacji korporacyjnych wzrosła aż o 342\% (tab. 1). CAGR ${ }^{1}$ całego rynku nieskarbowych papierów dłużnych w latach 2006-2014 wyniósł $18,2 \%$, w tym największą dynamiką wzrostu charakteryzują się właśnie obligacje korporacyjne. W tym okresie CAGR tych instrumentów wyniósł $25,1 \%$, podczas gdy łącznie dla pozostałych instrumentów tworzących segment instrumentów nieskarbowych wyniósł $14,5 \%$ [Gałka, 2015, s. 2].

Dominacja przedsiębiorstw jako emitentów obligacji na rynku długu nieskarbowego w Polsce widoczna jest również pod względem wolumenu emisji od $2009 \mathrm{r}$. $\mathrm{Na}$ koniec 2014 r. podmioty te sprzedały papiery dłużne o wartości 21,3 mld zł na rynku krajowym, a 13 mld zł na rynkach zagranicznych. W tym czasie banki zdołały uplasować na polskim rynku obligacje za 11,2 mld zł (bez obligacji infrastrukturalnych BGK), a samorządy tylko $2,1 \mathrm{mln}$ zł (rys. 1).

Znaczenie obligacji korporacyjnych w rozwoju rynku nieskarbowych instrumentów dłużnych daje się zauważyć także w strukturze tego rynku ze względu na skale zadłużenia. Na obligacje przedsiębiorstw na koniec 2014 r. przypadał udział na poziomie $37,8 \%$, na obligacje banków $-34,9 \%$, natomiast do pozostałych instrumentów (obligacji komunalnych i krótkoterminowych papierów dłużnych) należało niespełna 14\% rynku [Kowalski, 2105, s. 1].

Rosnąca popularność obligacji wśród przedsiębiorstw widoczna jest również w liczbie ich emitentów. Od początku funkcjonowania rynku Catalyst liczba emitentów obligacji korporacyjnych wzrosła z sześciu w 2009 r. do 146 na koniec 2014 r. [www.gpwcatalyst.pl].

1 Skumulowany roczny wskaźnik wzrostu (Compound Annual Growth Rate - CAGR) to średni wskaźnik rocznego wzrostu w badanym okresie, przy założeniu, że roczne wzrosty są dodawane do wartości bazy następnego okresu. W przybliżeniu można przyjąć, że CAGR to średnia wartość wskaźnika wzrostu z każdego roku. 
Pobrane z czasopisma Annales H - Oeconomia http://oeconomia.annales.umcs.pl Data: 26/04/2023 11:48:36

NOWA USTAWA O OBLIGACJACH SZANSĄ NA OŻYWIENIE RYNKU DŁUGU...

Tab. 1. Dynamika wzrostu wartości rynku nieskarbowych instrumentów dłużnych w Polsce w okresie 2009-2014 (w mld zł)

\begin{tabular}{|l|c|c|c|}
\hline \multirow{2}{*}{ Rodzaj instrumentu } & \multicolumn{2}{|c|}{ Okres } & \multirow{2}{*}{ Przyrost (\%) } \\
\cline { 2 - 4 } & $\mathbf{3 1 . 1 2 . 2 0 0 9}$ & $\mathbf{3 1 . 1 2 . 2 0 1 4}$ & 342 \\
\hline Obligacje przedsiębiorstw & 12 & 53 & 171 \\
\hline Obligacje komunalne & 7 & 19 & 158 \\
\hline Obligacje banków & 19 & 49 & 90 \\
\hline KPD & 10 & 19 & 192 \\
\hline Razem & 48 & 140 & \\
\hline
\end{tabular}

Źródło: [Kowalski, 2015].

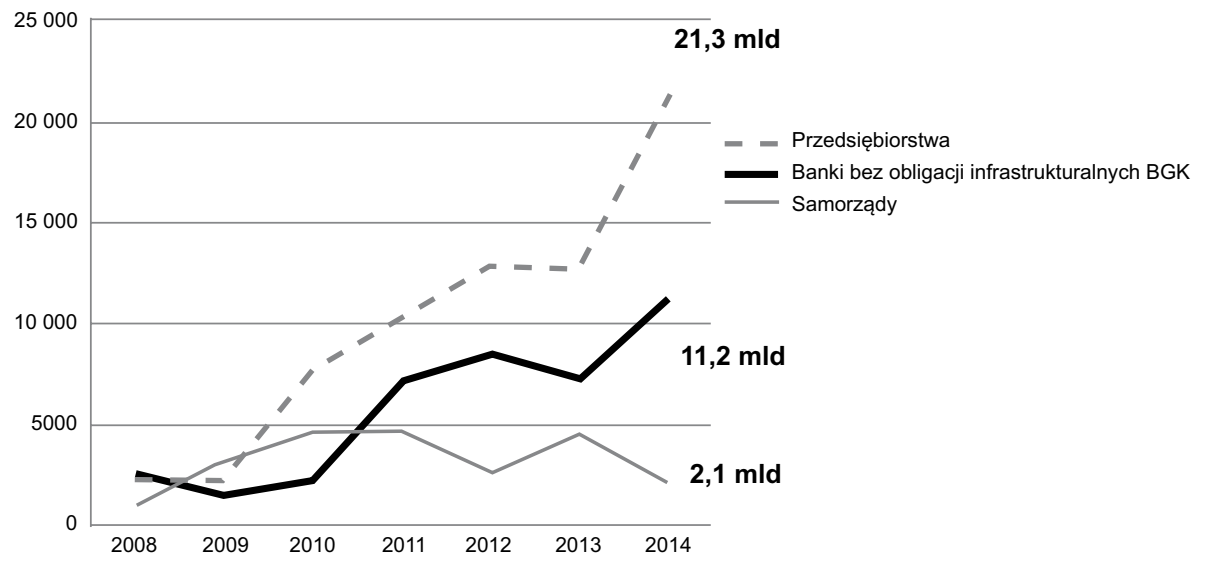

Rys. 1. Wielkość emisji obligacji nieskarbowych w okresie 2008-2014 (w mld zł)

Źródło: [Kowalski, 2015].

Impulsem do rozwoju obligacji korporacyjnych w Polsce okazał się upadek banku Lehman Brothers w 2009 r. Przedsiębiorstwa zorientowały się wówczas, że posiadanie jednego źródła finansowania (kredytu), którego podaż w tym roku została ograniczona, nie było dobrym rozwiązaniem. Podobny trend (ograniczenie podaży kredytów bankowych) dało się zaobserwować także w całej Europie. Korporacje europejskie, które - podobnie jak polskie - w dużym stopniu są uzależnione od finansowania bankowego, zwiększyły udział w finansowaniu długim z poziomu ok. $20 \% \mathrm{w} 2007 \mathrm{r}$. do $50 \% \mathrm{w} 2009 \mathrm{r}^{2}{ }^{2} \mathrm{~W}$ polskich warunkach w strukturze finansowania przedsiębiorstw w dalszym ciągu jednak prawie $88 \%$ stanowią kredyty, a tylko $12 \%$ - dług z tytułu emisji obligacji (rys. 2) [por. Pawłowski, 2015, s. 103-142].

2 Podobną tendencję można było zaobserwować przy kolejnej „odsłonie” problemów w europejskim sektorze bankowym w 2012 r. 


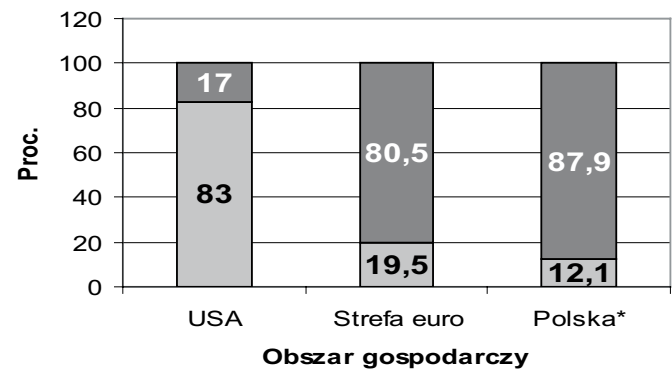

$\square$ Kredyty bankowe $\square$ Obligacje korporacyjne

Rys. 2. Struktura zobowiązań finansowych przedsiębiorstw: dla US i UE-17 (strefa euro) dane za 2013 r., dla Polski - dane za 2014 r.

Źródło: [Gałka, 2015].

Jednym z powodów słabości polskiego rynku papierów dłużnych jest struktura podaży. Większość ofert papierów korporacyjnych to emisje niewielkie, opiewające na ok. kilkadziesiąt milionów złotych, co odzwierciedla strukturę przedsiębiorstw polskiej gospodarki. W Polsce wartość większości emisji mieści się w granicach 50-100 mln zł i raczej jest mało prawdopodobne, by małe i średnie firmy decydowały się na emisje odpowiadające standardom europejskim, czyli o wartości odpowiadającej 100 mln euro. Konsekwencją niewielkiej skali emisji jest mała płynność obrotu i wynikający $z$ tego brak zainteresowania nimi zagranicznych inwestorów, którzy szukają większych ofert, a w związku z tym i bardziej płynnych.

Ryzyko płynności i wynikająca $z$ tego mała przejrzystość rynku dodatkowo są potęgowane brakiem powszechnych ratingów. Przykładowo na rynku Catalyst w połowie 2014 r. na obligacje korporacyjne posiadające ratingi przypadało co prawda $80 \%$ w rynku pod względem wartości emisji, ale tylko $20 \%$ ze względu na liczbę serii (rys. 3 i 4$)^{3}$.

Dość wspomnieć, że emitenci decydujący się na emisje o wartości nieprzekraczającej $100 \mathrm{mln}$ zł (czyli gros emisji) bardzo rzadko rozważają poddanie się ocenie ratingowej z uwagi na związany z tym dodatkowy koszt. Brak ratingów bezpośrednio wiąże się także z „nieoczekiwanym” niewykupieniem emisji przez emitenta. $\mathrm{Na}$ ponad 100 serii zapadających w 2014 r. 16 serii obligacji nie zostało wykupionych przez 14 emitentów. Ich łączna wartość wyniosła 149,9 mln zł, i choć w skali całego rynku nie są to duże kwoty, niemniej związany z tym spadek zaufania negatywnie wpływa na jego wizerunek.

3 W Europie przedsiębiorstwa bez ratingu nie mają szans na powodzenie emisji. Aż 90\% z nich ma co najmniej jeden. 
Pobrane z czasopisma Annales $\mathrm{H}$ - Oeconomia http://oeconomia.annales.umcs.pl

Data: 26/04/2023 11:48:36

NOWA USTAWA O OBLIGACJACH SZANSĄ NA OŻYWIENIE RYNKU DŁUGU...

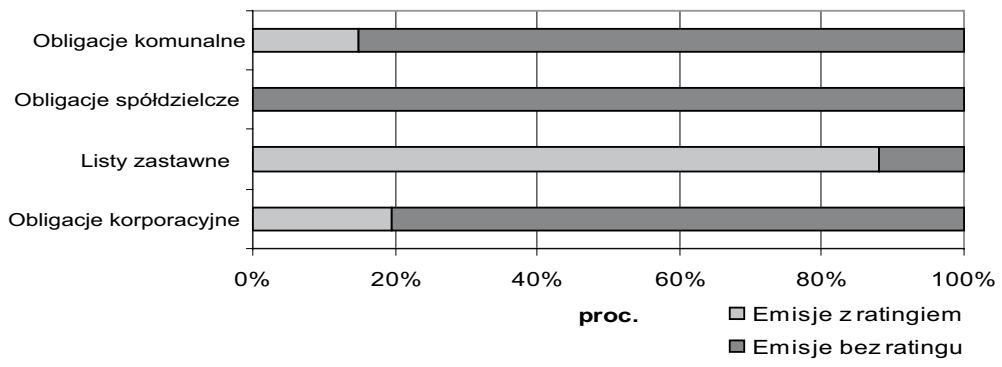

Rys. 3. Odsetek ilości serii obligacji posiadających rating na rynku Catalyst

Źródło: [Gontarek, 2015].

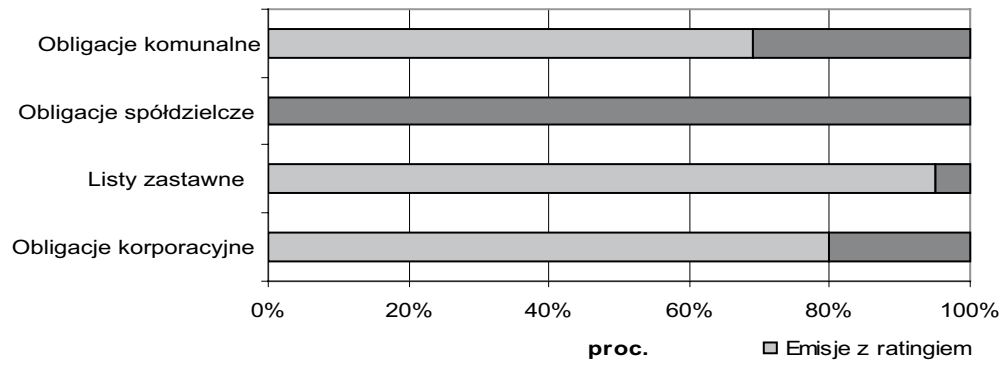

Rys. 4. Odsetek wartości emisji obligacji posiadających rating na rynku Catalyst

Źródło: [Gontarek, 2015].

Ryzyko płynności i wykupu emisji obligacji korporacyjnych sprawia, że emitenci - chcąc z sukcesem uplasować emisje na rynku - muszą decydować się na relatywnie krótkie terminy wykupu. Według danych Fitch Polska 42\% stanowią emisje do 3 lat (rys. 5). Maksymalne terminy zapadalności obligacji korporacyjnych na rynku długu nieskarbowego w Polsce to 5-7 lat w przypadku tzw. blue chipów i 2-3 lata dla pozostałych spółek.

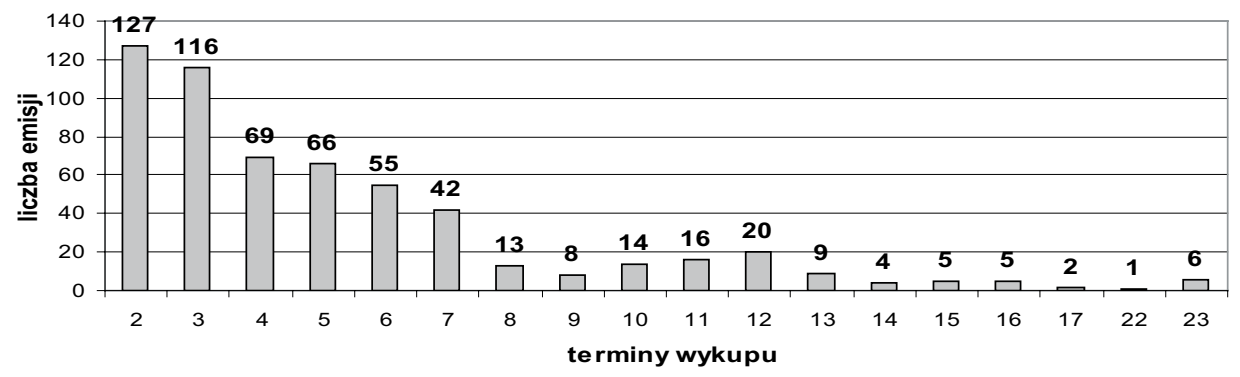

Rys. 5. Liczba emisji obligacji korporacyjnych ze względu na termin wykupu

Źródło: [Kowalski, 2015]. 
Rynek obligacji korporacyjnych w Polsce dobrze służy w zasadzie tylko pewnej grupie spółek. Są to albo duże i dobrze rozpoznawane przedsiębiorstwa, które przez emisję długu skutecznie dywersyfikują swoje źródła finansowania, albo spółki, które mogą mieć problem z uzyskaniem finansowania w bankach. Powodem trudności jest nie tyle brak zdolności kredytowej, co np. zbyt duża ekspozycja na nie banków lub też brak odpowiednich, akceptowanych przez banki zabezpieczeń. Thumaczy to wysoki udział deweloperów i spółek windykacyjnych wśród emitentów obligacji korporacyjnych.

Przechodząc do analizy rynku nieskarbowych instrumentów dłużnych od strony popytowej, należy zaznaczyć, że głównymi nabywcami tego typu instrumentów są banki, które będąc agentem emisji, znaczną jej część nabywają na własny rachunek, a tylko część sprzedają inwestorom (rys. 6).

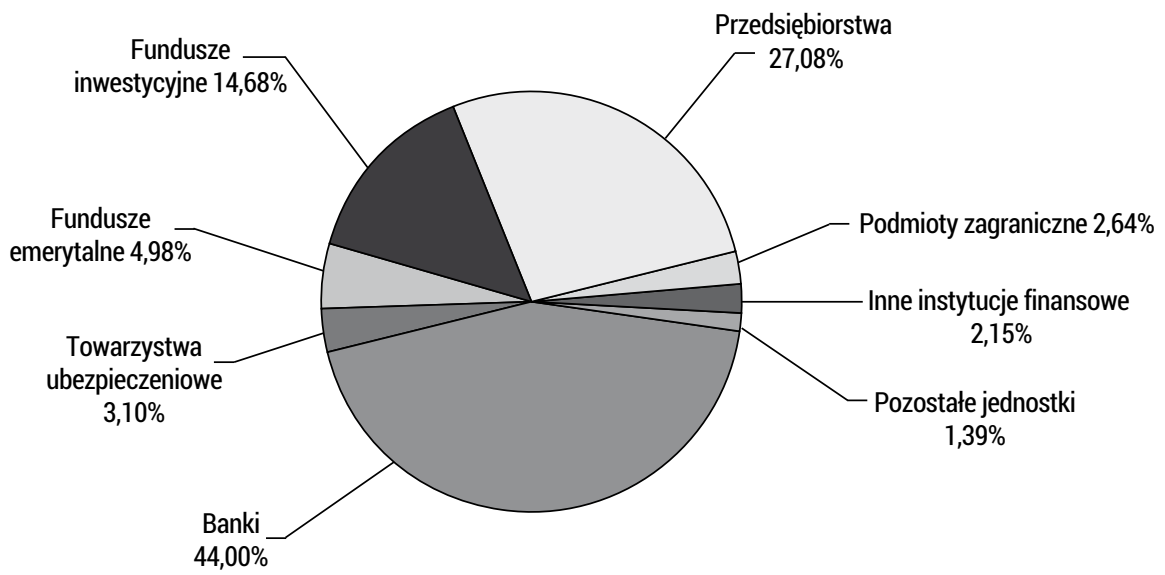

Rys. 6. Rodzajowe zróżnicowanie nabywców nieskarbowych papierów wartościowych (w \%)

Źródło: [Kowalski, 2015].

Drugim z kolei nabywcą papierów dłużnych są same przedsiębiorstwa. Obejmują one ponad $27 \%$ wszystkich emisji. Na dodatek w 2014 r. kupiły prawie $40 \%$ papierów emitowanych przez inne firmy. Tak duże zaangażowanie przedsiębiorstw może tłumaczyć chęć korzystniejszego w porównaniu z depozytami bankowymi ulokowania posiadanych nadwyżek płynności. Pozostałe 29\% emisji to inwestorzy instytucjonalni, czyli fundusze inwestycyjne, towarzystwa ubezpieczeniowe i OFE.

Ponadto można zauważyć, że struktura inwestorów również przyczynia się do niskiej płynności rynku, o której była już mowa. Powodem tego jest przyjęta przez większość inwestorów strategia inwestycyjna zakładająca trzymanie zakupionych obligacji do terminu wykupu.

Struktura popytu przesądza także o rzadkości ratingu. Większość emisji na rynek długu jest wprowadzana przez banki, które na ogół dobrze znając sytuację swojego klienta, same obejmują znaczną część emisji i są jej gwarantami. Z kolei OFE czy TFI 
zwykle dywersyfikują portfele „ilościowo”, kupując niewielkie partie licznych emisji. Stwarzają też presję na krótsze terminy zapadalności celem zachowania płynności.

\section{Szanse na ożywienie rozwoju rynku obligacji w Polsce}

Za zasadniczą szansę ożywienia rynku obligacji w Polsce należy uznać prognozowany wzrost gospodarczy Polski w najbliższych latach, którego natężenie ma być większe niż w innych krajach Unii Europejskiej [Analiza rynkowa, wrzesień 2013]. Rosnąca popularność obligacji jako instrumentu inwestycyjnego (i związany z tym wzrost zgłaszanego na nie popytu) pociąga za sobą nie tylko przyrost liczby emisji plasowanych na rynku pierwotnym, lecz także sprzyja poprawie ich płynności.

Coraz silniejsze dążenie firm, zwłaszcza tych dużych, do dywersyfikacji zadłużenia może być kolejną istotną szansą na rozwój rynku obligacji nieskarbowych. Na polskim rynku długu w 2013 i 2014 r. pojawiły się takie potęgi, jak PKN Orlen (z programem emisji obligacji detalicznych), Energa, PGE, Tauron, a w lutym $2015 \mathrm{r}$. Enea, z emisjami na co najmniej miliard złotych. W ślad za blue-chipami na rynku długu pojawiają się stopniowo spółki o średniej kapitalizacji (tzw. mid-cups), również z zamiarem dywersyfikacji finansowania. W przeciwieństwie do tych pierwszych, prawdopodobnie będą one wybierać częściej rynek polski niż zagraniczny, przy czym oferty mają szansę przekroczyć $100 \mathrm{mln}$ zł, przez co staną się atrakcyjne także dla inwestorów zagranicznych. Póki co polscy emitenci nie wykorzystują jednak nadarzającej się w warunkach niskich stóp procentowych okazji, jakimi są emisje o stałym oprocentowaniu.

Aby rynek obligacji w Polsce mógł się rozwijać, istotne jest uwiarygodnienie go przez nieustanne monitorowanie związanego z nim ryzyka. Od 20 czerwca 2014 r. zajmuje się tym Instytut Analiz i Ratingu (IAiR) ${ }^{4}$, powołany przez GPW w Warszawie S.A., której najważniejszym zadaniem jest popularyzacja rynku obligacji [www.gpw.pl] $]^{5}$.

Ożywieniu rynku obligacji nieskarbowych w Polsce powinny sprzyjać także regulacje Bazylea III. Na ich mocy od 2010 r. banki muszą stopniowo przygotowywać się do spełnienia norm płynnościowych (NSFR). Na tej podstawie, docelowo od 2018 r., banki mają finansować długoterminowe aktywa będące w ich posiadaniu długoterminowymi pasywami, cechującymi się zapadalnością powyżej roku. Rozwiązanie to powinno skierować uwagę banków na rynek obligacji jako źródła długoterminowego finansowania działalności, stanowiąc dodatkowy impuls jego rozwoju.

\footnotetext{
4 Inną agencją ratingową na rynku polskim jest Fitch Polska S.A., która w 2001 r. przejęła wcześniej działającą na polskim rynku agencję ratingową Środkowoeuropejskie Centrum Ratingu i Analiz (CERA).

5 GPW S.A. w Warszawie, w której strategii jednym z sześciu filarów jest rozwój rynku długu, rozważa, czy nie wprowadzić obowiązku ratingu przynajmniej w przypadku ofert publicznych obligacji.
} 
Szansą dla rynku obligacji mogą być też zmiany w OFE. Od początku 2014 r. mają one zakaz nabywania obligacji Skarbu Państwa, mogą natomiast pomnażać swe składki przez inwestycje w obligacje korporacyjne, samorządowe czy listy zastawne [emerytura.gov.pl]. Niemożność inwestowania przez OFE w obligacje skarbowe, które dotychczas stanowiły znaczną część ich portfela inwestycyjnego, powinna wesprzeć zgłaszany popyt na nieskarbowe obligacje.

Pozytywną zmianą dla rynku obligacji spółdzielczych jest wprowadzenie do polskiego prawa na początku 2013 r. dyrektywy CRD IV [Dyrektywa, 2013]. Na jej mocy zostały wprowadzone ostrzejsze normy płynnościowe stosowane przez banki spółdzielcze. Efektem obowiązywania dyrektywy CRD IV jest rosnące zainteresowanie banków emisją długu niepodporządkowanego w formie obligacji spółdzielczych, co stanowi atrakcyjną ofertę ulokowania nadwyżek kapitału.

Wreszcie niewątpliwą szansę dla rozwoju polskiego rynku nieskarbowych obligacji stanowi podpisana 2 lutego 2015 r. nowa ustawa o obligacjach, która weszła w życie z dniem 1 lipca 2015 r. [Ustawa, 2015].

\section{Główne zmiany przewidziane w nowej ustawie o obligacjach}

Do najważniejszych zmian, jakie przewiduje nowa ustawa o obligacjach w stosunku do „starych” rozwiązań należy zaliczyć:

- rozszerzenie katalogu emitentów,

- wprowadzenie nowych rodzajów obligacji,

- uregulowanie zasad dokonywania zmian w warunkach emisji m.in. przez wprowadzenie instytucji zgromadzenia obligatariuszy,

- rozstrzygnięcie wątpliwości towarzyszących obowiązującym regulacjom.

Nowy tekst ustawy rozszerza krąg podmiotów, które posiadają zdolność emisyjną o podmioty zagraniczne i spółki celowe. Dzięki przyjętym rozwiązaniom z jednej strony możliwa jest emisja na krajowym rynku obligacji podmiotów z zagranicy, a z drugiej pojawia się szansa np. dla sąsiadujących samorządów, które - tworząc spółkę celową - będą w stanie pozyskać środki na finansowanie wspólnych inwestycji. Dojdzie wówczas do emisji tzw. obligacji projektowych, których idea opiera się na wniesieniu przez podmiot publiczny do spółki celowej środków publicznych w formie tzw. długu podporządkowanego, co ostatecznie podniesie wiarygodność emitowanych obligacji. Ich celem jest finansowanie kluczowych projektów, np. z zakresu energetyki, transportu, technologii informatycznych czy komunikacyjnych [por. Puszer, 2014] ${ }^{6}$. Możliwość emisji obligacji przez spółki celowe otwiera także drogę tzw. emisjom sekurytyzacyjnym.

${ }^{6}$ Koncepcja obligacji projektowych pojawiła się w projekcie pilotażowym Strategia Europa 2020 [ec.europa.eu/europe2020/index_pl.htm]. 
Kolejna istotna zmiana przewidziana w nowej ustawie jest związana z możliwością wykorzystania nowych - oprócz już wspomnianych obligacji projektowych - rodzajów obligacji. Mowa jest o obligacjach wieczystych i podporządkowanych ${ }^{7}$. Poza klasycznymi zaletami, jakie są z nimi związane, ich przydatność może być rozpatrywana w szczególności z punktu widzenia banków, bowiem mogą one im posłużyć jako instrument pozwalający na spełnienie wymogów dotyczących płynności i kapitałów własnych.

Nowa ustawa usuwa również wątpliwości co do zakresu odpowiedzialności emitenta w przypadku obligacji przychodowych, których konstrukcja została stworzona m.in. z myślą o samorządach terytorialnych [por. Cichy, 2013]. Uprawniają one obligatariuszy do zaspokojenia roszczeń z pierwszeństwem przed innymi wierzycielami emitenta. Do zalet tego typu obligacji, które nowa ustawa utrzymuje, należy zaliczyć przede wszystkim (gdy emitentem jest J.S.T.) brak konieczności stosowania prawa zamówień publicznych do zamówien, których przedmiotem były usługi finansowe związane z emisją, sprzedażą i kupnem obligacji. Poza tym zobowiązań wynikających $\mathrm{z}$ tych obligacji nie uwzględnia się przy ustalaniu ograniczeń zadłużenia jednostek samorządu terytorialnego ${ }^{8}$. Nowe przepisy stanowią natomiast, że można emitować obligacje przychodowe, za które emitent przyjął odpowiedzialność całym swoim majątkiem9 . Warto odnotować fakt pojawienia się możliwości nadania obligatariuszom pierwszeństwa do zaspokojenia roszczeń z przychodów i majątku przedsięwzięć, sfinansowanych tylko w części ze środków uzyskanych z emisji obligacji.

Kolejna ważna zmiana dotyczy sposobności zmiany ustalonych przez emitenta warunków emisji. Określają one wszelkie świadczenia wynikające z obligacji, sposób ich realizacji, jak również prawa i obowiązki emitenta oraz obligatariuszy. $\mathrm{O}$ zmianę warunków emisji obligacji jest teraz łatwiej niż „pod rządami” starej ustawy, jednak pozostanie to $i$ tak wydarzeniem wyjątkowym ${ }^{10}$. Nowa ustawa o obligacjach dopuszcza zatem zmianę warunków emisji praktycznie w trzech trybach, takich jak:

7 W przypadku obligacji podporządkowanych, wierzytelności z nich wynikające - w razie upadłości lub likwidacji emitenta - będą regulowane po zaspokojeniu wszystkich innych wierzytelności przysługujących wierzycielom wobec emitenta. Nowa ustawa natomiast precyzuje, że zobowiązania z tego typu obligacji w przypadku upadłości lub likwidacji emitenta podlegają zaspokojeniu w kolejności wskazanej w warunkach emisji. Z kolei z istoty obligacji wieczystych wynika, że świadczenie emitenta względem obligatariuszy polega przede wszystkim na spłacie odsetek.

8 Jednostki samorządu terytorialnego nie korzystały $\mathrm{z}$ tego typu obligacji zbyt często. Pod rządami starej ustawy doszło w Polsce jedynie do sześciu takich emisji.

9 Wyemitowanie tak zabezpieczonych obligacji, np. przez samorząd Lublina, wzbudziło wątpliwości Regionalnej Izby Obrachunkowej.

10 Choć warunki rynkowe oraz sytuacja emitenta niejednokrotnie wymuszały wprowadzanie modyfikacji warunków emisji, to „stara” ustawa o obligacjach pomijała możliwości zmiany warunków emisji. Zmiana warunków emisji mogła być dokonywana wyłącznie w drodze porozumienia emitenta ze wszystkimi obligatariuszami. Brak zgody lub nawet milczenie choćby jednego z nich wyłącza możliwość jakichkolwiek korekt. Zawieranie takich ugód jest trudne technicznie, a w przypadku obligacji notowanych na giełdzie - niejednokrotnie niemożliwe. 
1) oświadczenie emitenta, 2) porozumienie z każdym obligatariuszem, 3) uchwała zgromadzenia obligatariuszy i zgoda emitenta.

$\mathrm{W}$ ramach pierwszego trybu emitent może w niewielkim i jedynie technicznym zakresie samodzielnie zmienić warunki emisji wyemitowanych przez siebie obligacji. W ten sposób będzie mógł wskazać:

- nowego tzw. administratora hipoteki lub zastawu,

- nowy podmiot prowadzący ewidencję obligacji lub depozyt,

- dodatkowe zabezpieczenia wierzytelności wynikających z obligacji.

Tryb ten ma zatem charakter jedynie aktualizujący warunki emisji o te dane, które zmienią się na skutek różnych zdarzeń. Te korekty, będąc de facto jedynie swoistego rodzaju komunikatami, nie mają istotnego wpływu na zakres praw i obowiązków zarówno emitenta, jak i obligatariuszy.

W nowej ustawie utrzymano stosowaną dotychczas praktykę dopuszczającą zmianę warunków emisji przez zawarcie porozumienia z każdym z obligatariuszy. Metoda ta może być stosowana do obligacji pozostających w posiadaniu niewielkiej grupy obligatariuszy, którzy są znani emitentowi i ma z nimi kontakt. Dotyczyć to będzie głównie obligatariuszy dokumentowych i tych rejestrowanych w ewidencjach (łatwość identyfikacji).

Trzeci tryb - novum - przewiduje zmianę warunków emisji wolą większości obligatariuszy. Mogą oni podejmować decyzje w tym zakresie za pośrednictwem gremium, jakim jest zgromadzenie obligatariuszy (bondholders meeting). Istnienie takiego organu musi być przewidziane $\mathrm{w}$ warunkach emisji zgodnie $\mathrm{z}$ zasadą, że zmiana może dotyczyć tzw. postanowień kwalifikowanych warunków emisji, czyli przede wszystkim:

- wysokości świadczeń i sposobu jej ustalania,

- realizacji świadczeń,

- wysokości, formy i warunków zabezpieczenia,

- zasad przeliczania świadczeń niepieniężnych na pieniężne,

- zasad funkcjonowania zgromadzenia obligatariuszy.

Zmiana innych postanowień wymaga odpowiedniego zastrzeżenia w warunkach emisji. Uchwała o zmianie warunków emisji musi uzyskać kwalifikowaną większość 3/4 głosów, a w wypadku obligacji dopuszczonych do obrotu zorganizowanego (rynek regulowany albo ASO) konieczna jest zgoda wszystkich obligatariuszy obecnych na zgromadzeniu (wymóg ten może powodować spore trudności w restrukturyzacji zadłużenia). Sama uchwała obligatariuszy nie wystarczy do zmiany warunków emisji. Dla jej ważności konieczna jest jeszcze akceptacja jej warunków przez emitenta, który był, jest i będzie ,gospodarzem” całego procesu. Oświadczenie o wyrażeniu zgody emitent publikuje na swojej stronie internetowej, z tym że jeśli tego nie zrobi w terminie 7 dni od dnia zakończenia zgromadzenia obligatariuszy, to będzie to oznaczać brak aprobaty dla proponowanych zamian ${ }^{11}$.

${ }^{11} \mathrm{Z}$ trzecim trybem wiążą się jednak pewne wątpliwości. Nie została uregulowana kwestia związana z zaskarżaniem uchwał zgromadzenia obligatariuszy. Zwraca się także uwagę np. na trudność uzyskania 
Do innych zmian, jakie wprowadza nowa ustawa, należy zaliczyć:

- wyłączenie z przepisów o odsetkach maksymalnych oprocentowania obligacji (czyli maksymalnie czterokrotność wysokości stopy kredytu lombardowego NBP), co ma umożliwić emisje papierów o wysokich rentownościach (obligacji śmieciowych, junk bonds),

- wymóg sporządzenia warunków emisji w języku polskim, z wyjątkiem obligacji o wartości nominalnej stanowiącej równowartość co najmniej 100000 euro,

- umożliwienie emitentowi jednostronnej zmiany niektórych postanowień warunków emisji w przypadku ustanowienia przez niego dodatkowego zabezpieczenia,

- uszczegółowienie wymogów stawianych wobec warunków emisji przez dodanie kolejnych punktów określających informacje, które powinny zostać ujęte w tego rodzaju dokumencie, jest to m.in. informacja o stronie internetowej emitenta oraz obowiązek umieszczania na niej określonych w nowej ustawie informacji,

- wprowadzenie instytucji administratora zabezpieczeń w przypadku zabezpieczeń innych niż hipoteka i zastaw rejestrowy (np. poręczenie i weksel),

- możliwość ustanowienia zabezpieczenia po emisji obligacji,

- doprecyzowanie istniejących wymogów w zakresie wyceny przedmiotu zastawu lub hipoteki, będących zabezpieczeniem wierzytelności wynikających z obligacji.

\section{Zakończenie}

Podstawowym celem nowej ustawy o obligacjach nie jest już ochrona drobnych inwestorów, gdyż jest on obecnie realizowany przez ustawę o ofercie publicznej przewidującą instrumenty zapobiegające nadużyciom przy publicznej emisji papierów wartościowych (zarówno udziałowych, jak i dłużnych). Ustawa o obligacjach tworzy natomiast prostą, sprawną, elastyczną i nowoczesną infrastrukturę prawną dla kreacji papierów dłużnych i wykonywania praw z nich wynikających.

Możliwość łatwego uplasowania emisji na rynku długu może być ważną kartą przetargową w negocjacjach na temat oprocentowania kredytów bankowych. W efekcie rozwój rynku obligacji nieskarbowych jako alternatywy dla finansowania bankowego jest przede wszystkim w interesie emitentów. Niewykluczone, że gdyby rynek stał się dostatecznie płynny i głęboki, papiery dłużne stałyby się instrumentami drugiego, a może nawet pierwszego wyboru.

Dla rozwoju rynku byłoby dobrze, gdyby obligacje emitowały duże, znane i wiarygodne firmy. Wyłoniłaby się wówczas nowa możliwość inwestycyjna, a gdyby emisje były częstsze, inwestorzy by się do nich z pewnością przyzwyczaili. Zapewne wpłynęłoby to także pozytywnie na poprawę płynności rynku wtórnego. Inwestycja

zgody całego zgromadzenia obligatariuszy oraz fakt, że to emitent ma ponosić wszystkie koszty związane ze zwoływaniem zgromadzenia obligatariuszy. 
w dobre obligacje byłaby wówczas nie tylko rzadką okazją zależną od tego, czy akurat odbywa się jakaś emisja, ale stałą alternatywą wobec lokaty bankowej.

Sposobem na rozwój rynku obligacji może być również zachęcanie spółek z zagranicy do organizacji emisji w oparciu o polskie przepisy. Mogliby bowiem kierować emisje nie tylko do polskich inwestorów, ale i do zagranicznych, korzystając $\mathrm{z}$ potencjału tkwiącego $\mathrm{w}$ infrastrukturze polskiego rynku i polskich doradców.

Jeśli rynek zostanie odblokowany po stronie emitentów, powinien stać się atrakcyjny też dla inwestorów, m.in. ze względu na cechy obligacji nieskarbowych jako instrumentu dywersyfikacji ryzyka. Zwiększonemu popytowi mogą sprzyjać zwłaszcza zmiany w OFE, które nie mogą już inwestować w rządowe obligacje.

Nowelizacja zapisów ustawy o obligacjach stanowiła odpowiedź ustawodawcy na zgłaszaną przez rynek potrzebę ich „odświeżenia”. Pozostaje mieć nadzieję, że wprowadzone zmiany odpowiadają oczekiwaniom uczestników rynku, co powinno ich zachęcić do intensywniejszego korzystania z potencjału tkwiącego w tym nieco „uśpionym” segmencie rynku finansowego w Polsce.

\section{Bibliografia}

Analiza rynkowa, wrzesień 2013, www.investors.pl [data dostępu: 14.04.2015].

Cichy J., Emisja obligacji przychodowych - niewykorzystany obszar aktywności banku, [w:] I. Pyka, J. Cichy (red.), Innowacje w bankowości i finansach, Studia Ekonomiczne. Zeszyty Naukowe Wydziałowe nr 171, Wydawnictwo Uniwersytetu Ekonomicznego w Katowicach, Katowice 2013.

Dyrektywa Parlamentu Europejskiego i Rady 2013/36/UE z dnia 26 czerwca 2013 r. w sprawie warunków dopuszczenia instytucji kredytowych do działalności oraz nadzoru ostrożnościowego nad instytucjami kredytowymi i firmami inwestycyjnymi, zmieniająca dyrektywę 2002/87/WE i uchylająca dyrektywy 2006/48/WE oraz 2006/49/WE, L 176/338.

ec.europa.eu/europe2020/index_pl.htm [data dostępu: 15.04.2015].

emerytura.gov.pl [data dostępu: 18.04.2015].

Gałka T., Ewolucja rynku obligacji korporacyjnych w Polsce, wystąpienie na seminarium pt. „Korporacyjny rynek papierów dłużnych w Polsce: aktualny stan, problemy, perspektywy rozwoju”, Warszawa, 5 marca $2015 \mathrm{r}$.

Gontarek A., Catalyst - katalizator rozwoju rynku instrumentów dlużnych: potencjał, aspiracje, możliwo$\dot{s} c i$, wystąpienie na seminarium pt. „Korporacyjny rynek papierów dłużnych w Polsce: aktualny stan, problemy, perspektywy rozwoju", Warszawa, 5 marca 2015 r.

Kowalski P., Rozwój rynku obligacji pozarządowych w Polsce na tle porównawczym, wystąpienie na seminarium pt. „Korporacyjny rynek papierów dłużnych w Polsce: aktualny stan, problemy, perspektywy rozwoju", Warszawa, 5 marca $2015 \mathrm{r}$.

Pawłowski M., Rynek obligacji korporacyjnych w Polsce. Uwarunkowania i perspektywy rozwoju, CeDeWu, Warszawa 2015.

Puszer B., Obligacje projektowe jako innowacyjny instrument finansowania strategicznych projektów w ramach UE, [w:] J. Harasim, W. Gradoń (red.), Innowacje a wzrost gospodarczy, cz. 2, Studia Ekonomiczne nr 186, Wydawnictwo Uniwersytetu Ekonomicznego w Katowicach, Katowice 2014.

Ustawa z dnia 15 stycznia 2015 r. o obligacjach (Dz.U. z dnia 20 lutego 2015 r., poz. 238).

www.gpw.pl [data dostępu: 15.04.2015].

www.gpwcatalyst.pl [data dostępu: 15.02.2015]. 


\section{The New Act on Bonds Opportunity to Revitalize the Non-Treasure Debt Market in Poland}

Low interest rates close to zero should encourage operators to increase the scale of debt in the financial market. In Poland low efficiency of market debt instruments is not conducive to this. On the 1st of July 2015 the new law on the bonds came into force, which modified some existing laws and introduced new solutions. The new rules should encourage issuers to more frequent recourse to bonds and revive trading on the secondary market. The purpose of this article is to analyze the market treasury bonds, identificate of barriers to its development and bring changes which provides for a new text of the Act on Bonds, together with an attempt to identify their impact on the increasing popularity of non-treasure debt market in Poland.

\section{Nowa ustawa o obligacjach szansą na ożywienie rynku długu nieskarbowego w Polsce}

Niski poziom stóp procentowych (bliski zera) powinien zachęcać podmioty gospodarcze do zwiększenia skali zadłużania się na rynku finansowym. W Polsce nie sprzyja temu niska efektywność rynku instrumentów dłużnych. 1 lipca 2015 r. weszła w życie nowa ustawa o obligacjach, która zmodyfikowała część dotychczasowych przepisów oraz wprowadziła nowe rozwiązania. Nowe przepisy powinny pobudzić emitentów do częstszego sięgania po obligacje oraz ożywić obrót na rynku wtórnym. Celem niniejszego artykułu jest analiza rynku obligacji nieskarbowych, identyfikacja barier jego rozwoju oraz przybliżenie zmian, jakie przewiduje nowy tekst ustawy o obligacjach, wraz z próbą wskazania ich wpływu na zwiększenie popularności rynku długu nieskarbowego w Polsce. 